\title{
Constitutive metaphor and mental mappings: meaning construction in the language of science and technology
}

\author{
Pilar Durán-Escribano ${ }^{1}$ \\ Universidad Politécnica de Madrid
}

\author{
Georgina Cuadrado-Esclapez \\ Universidad Politécnica de Madrid
}

\begin{abstract}
The study of scientific and technical language, where metaphor is central, is enriched by the cognitive linguistics approach. This paper is based on the research project that culminated in the Bilingual Dictionary of Scientific and Technical Metaphors and Metonymies1, developed to depict metaphorical terms and mental mappings, thus unfolding cognitive metaphors in science and technology. Although terminological metaphors as a whole exceed widely in number those that constitute part of conceptual metaphors, the importance of the latter radicates in its relevance as a constitutive element of scientific thought and language. Focusing on the analysis of metaphorical terms from earth sciences, agronomy, and mechanical engineering, the study reveals the presence of several conceptual metaphors, typified as 'humanizing', 'organicist', and 'objectual', according to their source domain's nature. The work presents some very productive conceptual metaphorical patterns found in knowledge representation in engineering, in English and in Spanish, and shows evidence that metaphorical reasoning is a mechanism present at the core of creative scientific development albeit certain socio-cultural variations. This contribution opens a door for further research on the role of metaphor in constructing meaning within all branches of science and technology, as well as on the study of knowledge representation variations in different languages and cultures.
\end{abstract}

Key words: science communication, conceptual metaphor, constitutive metaphor, scientific vocabulary.

\footnotetext{
${ }^{1}$ Corresponding author - Universidad Politécnica de Madrid, Avda. España 16, 4 A, 28231 Las Rozas de Madrid, Spain.

E-mail: pilar.duran@upm.es.
} 


\section{RESUMEN}

El estudio del lenguaje de la ciencia y la tecnología, en el que la metáfora es un elemento esencial, se enriquece con el enfoque de la lingüística cognitiva. Este artículo se basa en el proyecto de investigación que culminó con el Diccionario Bilingüe de Metáforas y Metonimias Científico-Técnicas1, llevado a cabo para detectar los términos metafóricos y los mapas mentales y así desvelar las metáforas cognitivas presentes en la ciencia y la tecnología. Aunque el total de metáforas terminológicas supera en número a las que forman parte de una metáfora conceptual, la importancia de éstas últimas radica en su relevancia como elementos constitutivos del pensamiento y el lenguaje científico. Comenzando con el análisis de términos metafóricos y centrándonos en las ciencias de la tierra, la agronomía y la ingeniería mecánica, el estudio revela la presencia de numerosas metáforas conceptuales tipificadas como 'humanizantes', 'organicistas' y 'basadas en objetos', según la naturaleza del dominio fuente. El trabajo presenta ciertos patrones de metáforas conceptuales muy productivos, encontrados en la representación del conocimiento científico en inglés y español y evidencia que el pensamiento metafórico es un mecanismo central en el desarrollo creativo de la ciencia, con algunas variaciones socioculturales. Esta contribución anima a profundizar en el papel de la metáfora en la construcción de significado en todas las ramas de la ciencia y la tecnología, y en cómo dicha representación puede variar en diversas lenguas y culturas.

Palabras clave: comunicación científica, metáfora conceptual, metáfora constitutiva, vocabulario científico.

\section{Introduction}

Within the universe of Languages for Specific Purposes (LSP), the presence of metaphor deserves special attention due to its relevance in meaning construction. In this respect, Lakoff and Johnson (1980, p. 4) affirm, "Primarily on the basis of linguistic evidence, we have found that most of our ordinary conceptual system is metaphorical in nature". The authors define the essence of metaphor as "understanding and experiencing one kind of thing in terms of another" (Lakoff \& Johnson (1980, p. 5) and emphasize the coherent and systematic character of metaphors, as they represent the materialization of thinking mechanisms that allow the representation, the understanding, the organization and the expression of knowledge. Although independent metaphorical terms that may be considered linguistic metaphors (Evans, 2013, p. 74) exceed widely in number those that respond to a conceptual metaphor, the importance of the latter is particularly important since conceptual metaphors are a rich source of constitutive elements of scientific and technical thought and language not duly studied so far.

Cognitive Metaphor Theory (CMT) (Lakoff, 1993) emphasizes that metaphors, which are based on human interaction with the world through physical experience, play a crucial role in the way humans conceptualize the world. As regards scientific language, 
four main tenets of CMT will be discussed along the paper: metaphor is central to abstract language; metaphors structure thinking and knowledge; metaphor is grounded in physical experience; and metaphor is culturally determined. Therefore, this article aims to fill a gap in the study of conceptual metaphor in scientific and technical language, giving evidence of their role in structuring thought and knowledge. Consequently, we will verify that the global scientific community shares similar conceptual metaphors to structure knowledge and to communicate scientific findings and their developments, though with different emphases according to the languages and cultures analysed in this paper, English and Spanish. We will also show that the metaphors found are all grounded in physical experience: in man's perception of himself as human, in the body functions, and in his perception of the material inanimate world around him.

However, whereas in general language the domain from which new concepts are drawn -the source domain- is generally considered to be concrete, and the target domain abstract, metaphor in science and technology does not always follow this pattern. In a previous work, Cuadrado and Durán (2013a) proposed a semantic hierarchy of terminological metaphors based on the distance from target to source domains, that is, on their metaphorical gradability. This means that the more semantic properties the source domain shares with the target domain (scientific terms), the less metaphorical a metaphor is, and vice versa. However, that study included only the conceptual metaphors and their related English terms, and no comparison was made with similar Spanish metaphors and their productivity. In this paper, we provide several new cases of conceptual metaphor in both English and Spanish versions, and compare and categorise them according to their proximity to human experience: the human person, the body, and the external world of inanimate objects as perceived by the scientist. We consider this new focus a good way to help science and engineering students of English (EST students) to understand meaning construction in their special fields and to assimilate their vocabulary more easily.

In the following sections, we will first outline the basic premises of cognitive theory and explain the typology of metaphors used for the study. Next, we will describe the specific referential corpus chosen for this purpose and the methodology followed to depict metaphorical expressions. Then, we will discuss the most representative conceptual mappings and the metaphorical terms involved, classifying them into the humanizing, organicist, and objectual types, according to the nature of the source domain. Finally, comparing and contrasting conceptual metaphors in English and Spanish we will touch on cultural aspects of both languages, which we expect will facilitate learners of EST to comprehend their specific vocabularies better. 


\section{Theoretical background}

\subsection{Basic principles}

This research article is grounded in Cognitive Semantics and the CMT. On the one hand, Cognitive Semantics principles provide a satisfactory explanation of how the scientific community generates metaphorical terms, accounting for the influence of history and culture. On the other, Cognitive Linguistics contributes to this with a theory of lexical semantics, which develops from the following basic principles: the Experiential Hypothesis (Johnson, 1997); categorization and the Prototype Theory (Rosh, 1977, 1978); and the CMT (Lakoff and Johnson, 1980, 1999; Lakoff, 1993).

The Experiential Hypothesis (Johnson, 1997) is based on the assumption that our mind is inherently embodied, i.e., meaning is grounded in and through our bodies and, consequently, much of our conceptual systems are either universal or widespread across languages and cultures. Lakoff and Johnson (1999) reaffirm this position in their work "The Embodied Mind and its Challenge to Western Thought", underlying that central aspects of language arise from sensory, motor and other neural systems. This view assumes that pre-conceptual experiences are an important primary source of metaphors, and, consequently, the development of metaphorical language is based on 'embodiment'.

The second principle is based on the Categorization and the Prototype theory (Rosch, 1978). Categorization relates to the basic human capability to identify entities as members of a group. Lakoff $(1987$, p. 6) highlights it postulating, "an understanding of how we categorise is central to any understanding of how we think and how we function, and therefore central to an understanding of what makes us human".

Thirdly, the Theory of Metaphor supports that metaphor consists of a mapping of concepts from the source to the target domain (Lakoff, 1987, Lakoff \& Johnson, 1999). It considers that metaphor is a basic mechanism for understanding and categorising the world, as well as a decisive tool in human reasoning. One important feature of metaphor, especially relevant for this work, lies in its potential to generate new meaning. In this respect, Lakoff \&Turner (1989, p. 23), explaining the role of metaphor in poetry as an example of how men think, point out:

Basic conceptual metaphors are part of the common conceptual apparatus shared by members of a culture. They are systematic in that there is a fixed correspondence between the structure of the domain to be understood (e.g., death) and the structure of the domain in terms of which we understand it (e.g., departure). We usually understand them in terms of common experiences.../ And they are widely conventionalized in language, 
that is, there are a great number of words and idiomatic expressions in our

language whose meanings depend upon those conceptual metaphors.

In this paper, we will confirm not only the pervasiveness of metaphor in scientific language, but also that it is widely conventionalized in scientific discourse within a given specific area. Thus, this analysis has focused on the study of conventional, lexical metaphors: that is, metaphors that have entered into the lexicon univocally. Although the force of the word is generally considered no longer active, we assume that those metaphors that have unconsciously been built into the language are important for understanding the mechanisms involved in scientific concept development, and the formation of related new words. For example, from the 'family' schema mapped onto rocks (table 2), we find a number of metaphorical expressions (parent rock, mother rock, ancestral rock, daughter element, etc) showing that the force of the metaphor is alive (Fauconnier, 1997, pp. 22 and 103).

Furthermore, in a study conducted by Boyd (1993), he established a link between metaphor and theoretical change and distinguished two main functions of metaphor in science: exegetical and constitutive; the latter is particularly relevant for our study, centred in constitutive metaphor. The former, the exegetical or explanatory function, is used to explain scientific concepts. For example, if we say 'the Colorado River is a sculptor that carves and chisels the Grand Canyon', the metaphorical expression 'a sculptor that carves and chisels' is exegetical to explain the river's erosion activity, whereas the metaphorical term 'canyon' is constitutive, i.e., it has become a geological term applied in different contexts. Thus, the constitutive function is present whenever metaphors become part of scientific thought, and, therefore, of concept development.

\subsection{Applications of cognitive theory of metaphor to science and technology}

Related to different scientific and technical areas, several authors have highlighted the importance of metaphor as a constituent part of their discourse (Boyd, 1993, Fahnestock, 1999; Brown, 2008, Musolff, 2009, Ciapuscio, 2011, Caballero \& Diaz-Vera, 2013). In this respect, Johnson-Sheehan (1997, p. 179) explains, "once a metaphor changes scientists' perspective concerning a particular phenomenon, it can then be used as an invention tool through which scientists re-conceptualize natural phenomenon in new ways". Other recent studies based on CMT have highlighted their importance as a constituent part of scientific and engineering discourse, and have analysed their role in theory building in different fields. Examples are Salager-Meyer (1990), in Medicine; White (2004), in Economy; Cuadrado (2010), in Mechanical Engineering; Robisco (2011), in Aeronautics; Cuadrado and Durán (2013a \& b) in science \& technology; Roldán-Riejos \& Úbeda Mansilla (2013), and Roldán-Riejos \& 
Molina Plaza (2016), in engineering; and Durán \& Argüelles (2016) in cross-disciplnary mappings between old sciences and new technologies. Today, evidence of the effectiveness of this approach to the study of metaphor use within different discourse communities continues to grow. Nevertheless, there remains a need for further research to explore new interactions within metaphorical terms' networks in the different fields of science.

\subsection{Main patterns for the classification of conceptual metaphor}

According to their source domain, conceptual metaphors in most scientific and engineering fields may be classified into three metaphorical patterns:

The humanizing pattern occurs when mappings originate from higher-order attributes of human beings such as purposeful behaviour and character. It is based on the classical conception of animism, projecting life, human emotions and temperament features onto inanimate entities. Thus, humanizing metaphors encompass the human being as a psychic entity (the mind, mental states, personality and temperament features), and the human being as a social being, in relationship to others. The cognitive metaphor STEEL IS A PERSON, which includes the mappings 'steel's life is human life' and 'steel's features are human traits', illustrates it (table 2).

Organicist metaphors take into account the body as a frame, as a container, and as a living organism including its growth and development and its functions. It is worth noting that some physiological aspects may be shared between animals and humankind, and that plant physiological attributes may be considered organicist when mapped onto objects. The cognitive metaphor SOILS ARE LIVING ORGANISMS, with terms referring to soil's life, age, and fertility, illustrates this pattern (table 2).

The third pattern is based on the general human perception of the appearance and/or function of inanimate entities, which we have called 'objectual'. An example is ROCK FORMATIONS ARE ARCHITECTURAL ELEMENTS.

These three mapping patterns are used to understand and categorize new scientific discoveries. They share a hierarchical classification of domains with Lakoff and Turner's (1989, pp. 167-168) "Great Chain of Beings Metaphor". However, their

\footnotetext{
${ }^{2}$ The authors refer to the hierarchical order of existing entities, from substances and inanimate objects to plants, animals, and human beings at the highest level. The higher the entity, the more complex it is. They discuss those mappings that apply to human feelings, emotions, life experiences and mental constructs (highest level target) to make them understood in terms of a lower level source; and those in the other direction of conceptualization from a higher source to a lower level target, where humans
} 
classification differs from ours in that the latter focuses on the rich amount of source domains used by scientists when giving name to new objective scientific realities rather than on the internal relationship of beings along the chain.

\section{Methodology and description of the referential corpus}

Based on the analysis of the terms found in engineering and other related fields, we started by developing a working database based on a cognitive semantic analysis of metaphorical lexical units and conceptual mappings ${ }^{3}$. This database culminated in 'The Bilingual Dictionary of Scientific and Technical Metaphors and Metonymies' (Cuadrado et al, 2016) (BDSTM), which is open to new additions. The Dictionary contains thirty-three conceptual metaphors from different engineering fields, but not all coincide with those selected for this paper. It has 23,125 entries, 11,000 SpanishEnglish and 12,125 English-Spanish lexical units. Nevertheless, in this article we will focus on three large areas: Agronomy, Earth sciences, and Mechanical engineering. Besides being the areas related to the engineering schools where we have worked, we consider the sample provided enough to support our arguments.

Thus, the unfolding of constitutive metaphors involved three stages:

Firstly, the search for metaphorical terms, including their definitions in their respective technical dictionaries, in English and in Spanish.

Secondly, contextualization of the selected metaphorical expressions to understand how they were used, mainly in the net, whenever necessary.

Finally, analysis of the metaphorical terms selected to establish conceptual metaphors and mappings, and to compare them in English and Spanish languages.

The metaphorical terms, and the cognitive metaphors and mappings were determined after a thorough analysis of the contextualised metaphors from a cognitive point of view. This procedure has allowed us to unveil the systematic metaphor patterns in each knowledge field, identifying and grouping topic domains and, finally, establishing groups of connected metaphors.

\subsection{Identification Procedure of Metaphorical Terminology}

Metaphor identification is no easy task as this depends primarily on the context in

serve to conceptualize complex physical objects.

${ }^{3}$ META-CITEC, a semantic database of scientific and technical metaphors. Project References: HUM0559/ M0700204155 (2009) \& QM101004060 (2012). Madrid Regional Government \& UPM. 
which metaphorical lexical units are found. With the purpose of avoiding individual subjective intuitions, we guided ourselves by the criteria proposed by the Pragglejazz Group (2007) when identifying metaphor. The procedure may be summarized in three steps:

Identify potentially metaphorical lexical items;

Determine whether the word can be understood in the specific context of what is being said beyond its literal general meaning; e.g. the contextual specific meaning of 'clad' in 'clad steel' is not "clothed", but "steel covered with a layer of another metal or alloy firmly bonded to it" (Dictionary of Mining Terms, p. 212).

Compare the basic and the new contextual meaning of the lexical items and determine the extent to which the specific term cannot be completely understood if only the general meaning is applied.

We adopted this procedure because it is considered the most flexible and widely used approach to the identification of metaphorical terms (e.g. Siqueira et al., 2009). Furthermore, Low (1999, p. 50) adds that, in identifying metaphorical terms, there is a problem related to familiarity with specific words, and that the researcher's knowledge of the topic may be considered a variable in metaphor identification. In this respect, as linguists and faculty members at Universidad Politécnica de Madrid (UPM), we have had the valuable opportunity of consulting with other academics expert in the areas dealt with, who also advised us in the selection of specialized dictionaries.

\subsection{The referential corpus}

As we said above, several technical dictionaries and online specific vocabularies were consulted to select those lexical units in which metaphor is involved. Table 1 shows the best-known monolingual and bilingual dictionaries featuring the three fields selected for this paper (agroforestry, earth sciences and mechanical engineering), listed by alphabetical order. Moreover, other dictionaries consulted to translate and compare meaning are included in the bibliography.

\begin{tabular}{lll}
\hline Name & Features & Entries \\
\hline $\begin{array}{l}\text { Anmol's Dictionary of Geology (1987/ } \\
\text { 1998). }\end{array}$ & $\begin{array}{l}\text { geology, mining and earth science terms } \\
\text { and definitions.- web linked. }\end{array}$ & 6,300 \\
\hline Dictionary of Mining terms (1967) & $\begin{array}{l}\text { 150,000 definitions of technical terms and } \\
\text { expressions related to mining, geology, }\end{array}$ & 55,000 \\
\hline
\end{tabular}


metallurgy, clays, and mineralogy, from the entire English-speaking world.

\begin{tabular}{|c|c|c|}
\hline $\begin{array}{l}\text { McGraw-Hill Dictionary of Scientific } \\
\text { and Technical Terms (2000) }\end{array}$ & $\begin{array}{l}125.000 \text { definitions of } 104 \text { fields related to } \\
\text { science and technology }\end{array}$ & 110,000 \\
\hline New Polytechnic Dictionary of & All engineering and related fields: & \\
\hline Spanish \& English Language (1988). & Volume I- & 275.000 \\
\hline $\begin{array}{l}2 \text { Vols: } \\
\text { English/Spanish \& Spanish/English }\end{array}$ & Volume II - & 300.000 \\
\hline $\begin{array}{l}\text { Oxford Dictionary of Geology \& Earth } \\
\text { Sciences. (2003/ 2008) }\end{array}$ & $\begin{array}{l}\text { Earth science terms and definitions, web } \\
\text { linked. }\end{array}$ & 6,250 \\
\hline $\begin{array}{l}\text { Oxford Dictionary of Environment } \\
\text { and Conservation (2007) }\end{array}$ & $\begin{array}{l}\text { economic, geographical, and political } \\
\text { terms and definitions, web linked. }\end{array}$ & 8,000 \\
\hline $\begin{array}{l}\text { Oxford Dictionary of Mechanical } \\
\text { Engineering (2014), T. Atking \& M. } \\
\text { Escudier }\end{array}$ & $\begin{array}{l}\text { heat transfer, combustion, robotics, and } \\
\text { measurement; other related areas as } \\
\text { acoustics, bioengineering, materials, } \\
\text { chemical, aeronautical \& environmental } \\
\text { engineering. It provides definitions, } \\
\text { examples \& illustrations. }\end{array}$ & 7,400 \\
\hline $\begin{array}{l}\text { The Penguin Dictionary of Electronics } \\
\text { (1988) }\end{array}$ & $\begin{array}{l}\text { Areas: solid-state devices and circuits; } \\
\text { semiconductor technology, including } \\
\text { associated fields as physics and computer } \\
\text { technology. }\end{array}$ & 2,200 \\
\hline
\end{tabular}

Table 1. Referential corpus used for the analysis of metaphorical terms

Other important sources of information consulted are The Oxford English Dictionary (1989), and the Collins English Dictionary (2006), which have provided additional information on scientific and technical terms.

All the terms selected constitute technical vocabulary, appearing systematically in a specialised language. As previously mentioned, we considered that all those entries involving mappings of any sort were accepted in the broadest sense as metaphors and, therefore, analysed and interpreted. Contextualization of lexicalized metaphors whenever the metaphorical use of a term was not clear was of great help before confirming its metaphorical use. This discourse approach to a first terminological analysis shed light on the understanding of conceptual metaphor patterns.

\section{Results and discussion}

The following results refer to quite productive cognitive metaphors, in terms of the quantity of lexical units involved within the fields studied. We will see that the three cognitive patterns discussed account for a great number of metaphorical terms and mappings (cf. tables 2, 3 and 4). 


\subsection{The humanizing pattern}

We start by the most anthropocentric pattern that includes the individual human being, and the human being as a social entity. We have found nine conceptual metaphors in the areas studied, except for mechanical engineering. In those cases where we observed terms relating both to the human being and to the animal and human body, we classified the metaphor under the highest anthropocentric pattern i.e. humanizing. For example, the metaphor A RIVER IS A HUMAN BEING, where terms such as "young", "adolescent", "mature", and "old" may be applied to both humans and animals (table 2).

The mapping of the human being as a person onto animals and things applies human life, character and behaviour to non-human beings. In the area of oenology, for instance, we find a very rich and powerful source of terminological metaphors in WINES ARE PEOPLE. It involves two mappings, 'wine features are human character' ("aggressive", "elegant", "feminine", "masculine", "sensual", etc) , and 'wine's cycle is human life's cycle' ("young", "mature", "decrepit"). The related metaphorical terms are as numerous in English as in Spanish, as shown in table 2. On the other hand, in the mapping 'Steel's life is human life' within the conceptual metaphor STEEL IS A PERSON, we found that some English metaphors referring to the human body are lost in Spanish, e.g. "hardfaced steel" ("acero cementado"), "skin hardened steel" ("acero cementado superficialmente"), and "bare steel" ("acero sin pintar").

A second facet of the humanizing metaphor is the mapping of human social aspects onto non-humans. It involves the concepts of family, community and society. We found a very powerful example in geology in the conceptual metaphor ROCKS AND MINERALS ARE HUMAN BEINGS, encompassing the mappings 'rock entities are human family members', and 'rocks are social beings', equally rich in English and in Spanish. The terms "consanguineous rocks", meaning rocks with equal mineral formation; "lineage", to describe a series of fossils that shows a course of evolution; and "community", "member", "native mineral", "host rock", etc., illustrate the power of this conceptual metaphor (table 2).

A different example belonging to the humanizing pattern is the metaphor of war, which is very frequent not only in general language but also in science and technology. Based on human activity, it is explicit in the conceptual metaphor taken from Agriculture PLANTS ARE HUMAN BEINGS. The mapping 'A plant's uncontrolled growth is an attack' contains the terms "attack", "antagonism", "invasion" and "invasive competition", in both languages. However, a slight difference in the metaphorical expressions present in English and Spanish is shown in the mapping 'Parts of a plant are parts of the body', as there are 11 English terms, and 7 Spanish terms. Four English terms do not have a metaphorical equivalent in Spanish, ("neck", "heart", "head", and 
"rib"); and "vein" is translated as "nervio", a different part of the body.

\begin{tabular}{|c|c|c|c|}
\hline $\begin{array}{l}\text { Conceptual } \\
\text { metaphor }\end{array}$ & $\begin{array}{l}\text { Field of } \\
\text { science and } \\
\text { technology }\end{array}$ & Mappings & Examples of metaphorical terms \\
\hline $\begin{array}{l}\text { STARS AND } \\
\text { PLANETS ARE } \\
\text { PEOPLE }\end{array}$ & $\begin{array}{l}\text { Planetary } \\
\text { science }\end{array}$ & $\begin{array}{l}\text { Groups of stars } \\
\text { are families } \\
\text {-Star types are } \\
\text { human traits }\end{array}$ & $\begin{array}{l}\text {-asteroid family, solar twin, host star. } \\
\text {-familia de asteroides, gemelo solar, galaxia } \\
\text { anfitriona. } \\
\text {-dwarf, dead, wandering / star; host } \\
\text { galaxy, red dwarf, red giant, white dwarf, } \\
\text { yellow dwarf; dwarf, lonely, nomad / } \\
\text { planet; gas giants. } \\
\text {-estrella enana, errante; cadáver estelar; } \\
\text { enana roja, gigante roja, , enana blanca, } \\
\text { enana amarilla; planeta enano, solitario, } \\
\text { nómada; gigantes gaseosos }\end{array}$ \\
\hline
\end{tabular}

$\begin{array}{lll}\text { STEEL IS A } & \text { Metallurgy \& } & \text {-Steel's life is } \\ \text { PERSON } & \text { minerallurgy } & \text { human life }\end{array}$

-sound, strain-aged, strain-aging, agehardenable, self-hardening, restored, hardfaced, skin hardened, bare, clad, lead-coated, dead, killed /steel -acero sano, envejecido, de envejecimiento por deformación, madurado (mecánicamente), endurecible /endurecido por reposo, auto-templable, revestido (chapado), regenerado, muerto -Steel's features -soft-centred, mild, quick speed, tough, are human traits passive (stainless steel), crack-sensitive, insensitive, lively, fiery, wild / steel. acero con alma suave, débil, rápido, de corte rápido, tenaz, calmado, (acero inoxidable) pasivo, insensible a la fisuración, sensibilizado, no calmado, (líquido) vivo.

\begin{tabular}{|c|c|c|c|}
\hline $\begin{array}{l}\text { ROCKS AND } \\
\text { MINERALS } \\
\text { ARE HUMAN } \\
\text { BEINGS }\end{array}$ & Geology & $\begin{array}{l}\text {-Rock entities and } \\
\text { minerals are } \\
\text { humans }\end{array}$ & $\begin{array}{l}\text {-parent, mother, barren, dead, live /rock; } \\
\text { twin, related, consanguineous/ rocks; } \\
\text { rock family; daughter element, twin } \\
\text { crystal, contact twin, twinning, twinning } \\
\text { plane; bedded ore. } \\
\text {-roca madre, estéril, viva, virgen; rocas } \\
\text { gemelas, relacionadas, de origen } \\
\text { consanguíneo; familia de rocas; mineral } \\
\text { nativo, elemento descendiente, mineral en } \\
\text { criadero. }\end{array}$ \\
\hline
\end{tabular}


-Rocks are social -community, population, member; host, beings intrusive, allied, enclosing/ rock; mineral association; accompanying/ mineral; docile, high, based/ ore..

- comunidad, población, miembro; roca hospedante, intrusiva, encajante; asociación de minerales, mineral asociado, dócil, rico, pobre.

\begin{tabular}{|c|c|c|}
\hline $\begin{array}{l}\text { RIVERS ARE } \\
\text { HUMAN } \\
\text { BEINGS }\end{array}$ & $\begin{array}{l}\text { Geology \& } \\
\text { Geography }\end{array}$ & $\begin{array}{l}\text {-A river's course } \\
\text { is human life's } \\
\text { cycle }\end{array}$ \\
\hline
\end{tabular}
-young, adolescent, rejuvenated, mature, old / river.

-nacimiento del río, río joven, adolescente, rejuvenecido, maduro, senil o viejo.

-A river is a -master, misfit, antecedent, rambling, person feeder, beheaded, tributary /river; competent stream -río maestro, empobrecido, antecedente, divagante, capturado, tributario.

\begin{tabular}{|c|c|c|c|}
\hline $\begin{array}{l}\text { WATER IS A } \\
\text { HUMAN } \\
\text { BEING }\end{array}$ & Hydrology & $\begin{array}{l}\text {-Water's life cycle } \\
\text { is human life } \\
\text { cycle } \\
\text {-Water's features } \\
\text { are human traits }\end{array}$ & $\begin{array}{l}\text {-connate, primitive, juvenile, dead /water } \\
\text {-agua connata, juvenil, muerta. } \\
\text { active, aggressive, congenital, running, } \\
\text { free, still, quiet /water. } \\
\text {-agua activa, agresiva, congénita, corriente, } \\
\text { libre, tranquila, tumultuosa, dormida, } \\
\text { enferma, madre }\end{array}$ \\
\hline $\begin{array}{l}\text { WINES ARE } \\
\text { PEOPLE }\end{array}$ & $\begin{array}{l}\text { Agriculture } \\
\text { (aenology) }\end{array}$ & $\begin{array}{l}\text {-Wine features } \\
\text { are human } \\
\text { character }\end{array}$ & $\begin{array}{l}\text {-wine character; aggressive, elegant, } \\
\text { dominant, soft, delicate, feminine, } \\
\text { masculine, sensual, balanced, sincere, - } \\
\text { vigorous, powerful, fortified, strong, } \\
\text { robust/ character; vigour in the mouth; } \\
\text { strength in the mouth; virility. } \\
\text {-carácter del vino; agresivo, elegante, } \\
\text { dominante, afable, delicado, femenino, } \\
\text { masculino, sensual, equilibrado, sincero, } \\
\text { vigoroso, potente, fortalecido, fuerte, } \\
\text { robusto, virilidad } \\
\text {-lively, young, mature, decrepit / wine } \\
\text {-vino vivo, joven, maduro, decrépito }\end{array}$ \\
\hline $\begin{array}{l}\text { PLANTS ARE } \\
\text { HUMAN } \\
\text { BEINGS }\end{array}$ & $\begin{array}{l}\text { Agriculture, } \\
\text { Botany }\end{array}$ & $\begin{array}{l}\text {-Parts of a plant } \\
\text { are parts of the } \\
\text { body } \\
\text {-The plant } \\
\text { circulatory } \\
\text { system is the }\end{array}$ & $\begin{array}{l}\text { Eye, finger, vein, root hairs, rib, heart, } \\
\text { neck, head, tissue, ovary, ovules. } \\
\text {-ojo, dedo, nervio, pelos radiculares, tejido, } \\
\text { ovario, óvulos. } \\
\text {-Vascular system, vascular bundle, } \\
\text { vascular tracheid, veins, vessels, } \\
\text {-sistema vascular, haz vascular, traqueidas }\end{array}$ \\
\hline
\end{tabular}




\begin{tabular}{llll} 
& & $\begin{array}{l}\text { body circulatory } \\
\text { system } \\
\text {-Plants' } \\
\text { organization is } \\
\text { humans' } \\
\text { organization }\end{array}$ & vasculares, vasos. \\
& -A plant's & -kingdom, community \\
& uncontrolled & -attack, antagonism, invasion, invasive \\
& growth is an & competition. \\
& attack & -ataque, antagonism, invasion, \\
& & & competencia invasiva \\
\hline BEESARE & Agriculture & & -queen, community, colony, workers, \\
HUMAN & (apiculture) & & carpenter bee, solitary bee. \\
SOCIETY & & & -reina, comunidad, colonia, obreras, abeja \\
& & & carpintera, abeja solitaria.
\end{tabular}

Table 2. 'Humanizing pattern' conceptual metaphors

\subsection{The organicist pattern}

The organicist metaphor ENTITIES AND THINGS ARE LIVING ORGANISMS has been found in all the areas studied, including mechanical engineering. We present six cases (table 3) where their productivity, in terms of the number of metaphorical terms present, is very similar in English and in Spanish $(9 / 8 ; 5 / 6 ; 7 / 8 ; 15 / 16)$ in the first four metaphors. However, there are slight differences in the metaphorical terms related to machinery, generally in favour of English terms, except for the last case $(6 / 3 ; 12 / 5$; 20/16 and 15/17). The characteristics of 'the body as a frame' and 'the body as a living organism' metaphors are discussed below table 3 .

\begin{tabular}{|c|c|c|}
\hline $\begin{array}{l}\text { Conceptual } \\
\text { metaphor }\end{array}$ & $\begin{array}{l}\text { Field of Mappings } \\
\text { science and } \\
\text { technology }\end{array}$ & $\begin{array}{l}\text { Examples of metaphorical } \\
\text { terms }\end{array}$ \\
\hline $\begin{array}{l}\text { ROCK PROCESSES } \\
\text { ARE PLANT } \\
\text { PROCESSES }\end{array}$ & $\begin{array}{l}\text { Geology and } \\
\text { mineralogy }\end{array}$ & $\begin{array}{l}\text {-Exfoliation, exfoliate, foliation, } \\
\text { rock outcrops, outcroppings, } \\
\text { crop-end, buried outcrop, rock } \\
\text { peeling, sand grains. } \\
\text { - Exfoliación, exfoliar, } \\
\text { afloramientos, aflorar, } \\
\text { afloramiento rocoso, enterrado; } \\
\text { descamación, granos de arena. }\end{array}$ \\
\hline $\begin{array}{l}\text { THE ENTRANCE } \\
\text { INTO A PIT OR A } \\
\text { MINE IS THE HEAD }\end{array}$ & $\begin{array}{l}\text { Mining } \\
\text { engineering }\end{array}$ & $\begin{array}{l}\text {-collar, lip, mouth, pit mouth, } \\
\text { wellhead. } \\
\text {-bocamina, boca, boca de galería, } \\
\text { boca activa, boca de salida, cabeza } \\
\text { de pozo. }\end{array}$ \\
\hline
\end{tabular}




\begin{tabular}{|c|c|c|c|}
\hline $\begin{array}{l}\text { SOILS ARE } \\
\text { LIVING } \\
\text { ORGANISMS }\end{array}$ & Agroforestry & & $\begin{array}{l}\text {-Soil life, / age, fertility, } \\
\text { exhaustion, skeleton; young } \\
\text { soils, to lie fallow. } \\
\text {-edad del suelo, fertilidad, vida, } \\
\text { agotamiento, fatiga, esqueleto; } \\
\text { suelos juveniles, descansar en } \\
\text { barbecho. }\end{array}$ \\
\hline $\begin{array}{l}\text { PLANT AND TREE } \\
\text { ACTIVITY CYCLE IS } \\
\text { A SLEEP-WAKE } \\
\text { CYCLE }\end{array}$ & Agroforestry & & $\begin{array}{l}\text {-dormancy; internal, seed, } \\
\text { predictive, rhizome winter, } \\
\text { consequential / dormancy; } \\
\text { dormancy needs; dormant seed, } \\
\text { tree, bud, state, tuber, phase; } \\
\text { quiescence; non-dormant seeds. } \\
\text {-dormición; dormancia interior, de } \\
\text { la semilla, predictiva, del rizoma, } \\
\text { invernal, consecuente; tubérculo } \\
\text { latente; fase de dormición o } \\
\text { latencia; semilla durmiente, árbol } \\
\text { durmiente, yema en reposo, } \\
\text { necesidad de reposo, estado } \\
\text { latente, semillas no latentes. }\end{array}$ \\
\hline \multirow[t]{2}{*}{$\begin{array}{l}\text { ENGINES ARE } \\
\text { ANIMAL BODIES }\end{array}$} & $\begin{array}{l}\text { Agriculture } \\
\text { (Farm } \\
\text { machinery) } \\
\text { Mechanics }\end{array}$ & $\begin{array}{l}\text {-The engine's } \\
\text { carburetor is the } \\
\text { respiratory system. }\end{array}$ & $\begin{array}{l}\text {-Exhaust system, exhaust pipe, } \\
\text { exhaust manifold, air strangler, } \\
\text { choke, throttle. } \\
\text {-ahogador, estrangular, } \\
\text { estrangulador. }\end{array}$ \\
\hline & & $\begin{array}{l}\text {-The engines' fuel } \\
\text { conduction system } \\
\text { is the digestive } \\
\text { system }\end{array}$ & $\begin{array}{l}\text {-Throat valve, feeder, feed valve, } \\
\text { feed wheel, feeding, feeding } \\
\text { device, feeding motion, feed } \\
\text { trough, feed drain tank, feeding } \\
\text { plunger, feed-control valve, } \\
\text { intake../ } \\
\text {-depósito alimentador, válvula de } \\
\text { alimentación, rueda de } \\
\text { alimentación, mecanismo } \\
\text { alimentador, válvula de control de } \\
\text { alimentación. }\end{array}$ \\
\hline $\begin{array}{l}\text { MACHINES ARE } \\
\text { ANIMALS }\end{array}$ & $\begin{array}{l}\text { Mechanics } \\
\text { Machinery }\end{array}$ & $\begin{array}{l}\text { Machine elements } \\
\text { are parts of the } \\
\text { body }\end{array}$ & $\begin{array}{l}\text {-finger; chute, driving, selecting / } \\
\text { finger; teeth; digger teeth, nicked } \\
\text { teeth, teethed drum, stub tooth, } \\
\text { neck ring, jaw coupler, coupling } \\
\text { ring, twine knotter head, crane } \\
\text { neck, crane arm, catch nose, } \\
\text { cross head, pigtail, claw jack, claw }\end{array}$ \\
\hline
\end{tabular}


crane

-dedo de retenida, guiador, impulsor, selector; dentadura, diente para cuchara excavadora, dientes con ranuras, tambor dentado, cabeza de anudador de hilo, brazo de grúa, diente o dedo de arrastre, cabeza de barra de conexión, mordaza dentada, gato de uña, grúa de garra,

Machines are animal species -cat, cat tackle, caterpillar crane, caterpillar tractor, clamshell grab, crawler crane, crawler tractor, crocodile spring grip, giraffe, pig, mole, beetle, horse (horsepower), haulage mule, walking tractor, -oruga, aparejo de gata, grúa de orugas, tractor oruga, grúa de almeja, jirafa, camión jirafa, topo, caballo (de vapor), mula de arrastre, mulilla mecánica, cigüeña, cigüeña compuesta, gato, gato de uña, pajarito, toro.

Table 3. 'Organicist pattern' conceptual metaphors

In the organicist pattern, the body structures mapped onto the different targets are based on the following schema: (a) the body as a frame containing parts and organs ("collar", "lip", "mouth" etc.), and (b) the body as a living organism, including the body functions ("soil fertility", "feeding device", etc.). In most metaphorical expressions, the concept 'body' is related to the human or animal body; however, plant organs have been accepted as an organicist source domain in relation to rocks. This is the case of Rock PROCESSES are plant PROCESSES, which includes the terms "exfoliation", "exfoliate", "foliation", "outcrop", "rock peeling" and "sand grains", equally present in English and Spanish languages (9/8).

'The body as a frame' relates to body anatomy metaphors, which involves the body as a container and the parts of the body. An important observation in this metaphor pattern is that most metaphorical terms are not created from an essential semantic attribute, but derive from the perception of their shape or function. It is the result of human imagination, as in the metonymic term "eye", derived from the transposition, 'a bud on a twig is an eye', or in "finger" in machinery, where the projecting piece brought into contact with an object to affect its motion is termed "finger".

MACHINES ARE ANIMALS is based on two different analogies: the shape of the 
machine ("clamshell grab", "giraffe"), or the function it performs ("mole", "mula mecánica"). Also interesting is the metaphor horse (horsepower) entangled with the metonymy "the animal for the power it has". Thus, horse power is explained as follows:

\begin{abstract}
In the British Imperial System, one horsepower equals 33,000 foot-pounds of work per minute-that is, the power necessary to lift a total mass of 33,000 pounds one foot in one minute. This value was adopted by the Scottish engineer James Watt in the late 18th century, after experiments with strong dray horses, and is actually about $50 \%$ more than the rate that an average horse can sustain for a day. (https://global.britannica.com/science/ horsepower)
\end{abstract}

This metaphor is found in English and in Spanish; nevertheless, there are some differences probably due to cultural reasons (Kövecses, 2010). In the mapping 'machine elements are parts of the body', the ratio between English/Spanish terms is 20/16; and in 'machines are animal species' it is 15/17, presenting slight difference in both languages. Moreover, the translation of the terms is not always literal while being metaphorical in both cases, e.g. "cat" ("oruga"); "caterpillar crane" or "crawler crane" ("grúa de orugas"); and "crocodile spring grip" ("mordaza dentada"). On the other hand, animal metaphors are sometimes lost, e.g. English terms "beetle" ("martinete") and "pig" ("trineo de aparejo") do not use the animal's name in Spanish. Spanish terms "cigüeña" ("sweep"); "gato" ("jack"); "pajarito" ("twine knotter head"); and "toro" ("forklift") disappear in English as a metaphor. Crocodiles are not common animals in Spain, whereas toros (bulls) are not common in English speaking countries.

The body as a living organism metaphorical pattern refers to body functions. The conceptual metaphor PLANT AND TREE activity CYCLE IS A SLEEP-wake CYCLE constitutes an interesting case in the field of agroforestry with nearly as abundant metaphorical expressions in English as in Spanish (15/16), though with not always literal translation. On the other hand, the body respiratory system is present in two examples taken from Agriculture. A first example found in the area of farm machinery is ENGINES ARE ANIMAL BODIES, which includes the mappings, 'the engine's carburettor is the respiratory system', and 'the engine's fuel conduction system is the digestive system'. In these mappings, the English terms are more abundant than those in Spanish: 6/3 in the first case, and 12/5 in the second.

\title{
4.3 Inanimate entities' features pattern
}

This pattern based on inanimate entities' characteristics, whether on their external appearance or their way of functioning, may be called 'objectual', as it refers to material objects. It is quite frequent in engineering (table 4). In the conceptual 
metaphor ROCK FORMATIONS ARE ARCHITECTURAL ELEMENTS, we find several examples of metaphorical terms, which relate to the external appearance of source and target items ("dome"), their function ("ceiling", "floor", "window"), and both aspects ("roof", "chamber", "chimney").

\begin{tabular}{|c|c|c|c|}
\hline $\begin{array}{l}\text { Conceptual } \\
\text { metaphor }\end{array}$ & $\begin{array}{l}\text { Field of } \\
\text { science and } \\
\text { technology }\end{array}$ & Mappings & $\begin{array}{l}\text { Examples of metaphorical } \\
\text { terms }\end{array}$ \\
\hline $\begin{array}{l}\text { ROCK } \\
\text { FORMATIONS ARE } \\
\text { ARCHITECTURAL } \\
\text { ELEMENTS }\end{array}$ & Geology & & $\begin{array}{l}\text { - dome, dome crest, dome fold, } \\
\text { salt dome, volcanic dome, ceiling, } \\
\text { roof, floor, window, chamber, } \\
\text { chimney. } \\
\text { - domo, cresta de domo, pliegue } \\
\text { abovedado, domo salífero, domo } \\
\text { volcánico, techo, suelo, ventana, } \\
\text { cámara, chimenea. }\end{array}$ \\
\hline $\begin{array}{l}\text { GENES ARE } \\
\text { CONTAINERS OF } \\
\text { INFORMATION }\end{array}$ & Biotechnology & & $\begin{array}{l}\text {-genetic code, map, file; gene } \\
\text { bank, library; barcode database } \\
\text { (of genes' distinct features). } \\
\text {-código genético, banco de genes, } \\
\text { genoteca, biblioteca genómica, } \\
\text { mapa genético. }\end{array}$ \\
\hline $\begin{array}{l}\text { WINES ARE } \\
\text { CLOTH }\end{array}$ & $\begin{array}{l}\text { Agriculture, } \\
\text { Aenology }\end{array}$ & $\begin{array}{l}\text {-Transposition of } \\
\text { touch-related } \\
\text { terms to taste } \\
\end{array}$ & $\begin{array}{l}\text { - velvety, silky, rough, soft.../ } \\
\text { - aterciopelado, sedoso, áspero, } \\
\text { suave. }\end{array}$ \\
\hline $\begin{array}{l}\text { AN EPICYCLIC } \\
\text { GEARING IS A } \\
\text { PLANETARY } \\
\text { GEARING. }\end{array}$ & $\begin{array}{l}\text { Agriculture } \\
\text { (farm } \\
\text { machinery) }\end{array}$ & & $\begin{array}{l}\text {-Sun, planetary, planet, planet } \\
\text { carrier, outer ring gear; planetary } \\
\text { gear train. } \\
\text {-engranaje planetario, tren de } \\
\text { engranajes planetario. }\end{array}$ \\
\hline $\begin{array}{l}\text { METALS ARE } \\
\text { FOOD }\end{array}$ & $\begin{array}{l}\text { Mining } \\
\text { engineering } \\
\text { Metallurgy }\end{array}$ & $\begin{array}{l}\text {-Transposition of } \\
\text { taste-related } \\
\text { terms to metal } \\
\text { properties }\end{array}$ & $\begin{array}{l}\text {-acid steel, ...l } \\
\text {-acero ácido, agrio, dulce, } \\
\text { semidulce, escoria dulce, fundición } \\
\text { dulce, hierro dulce, plomo dulce, } \\
\text { metal agrio, cobre agrio, hierro } \\
\text { agrio, dulce; plata agria; plomo } \\
\text { agrio. }\end{array}$ \\
\hline
\end{tabular}




\section{-Treating metals} is cooking food

-Treated metals' appearance is food's appearance

-roasted steel, roasting; heap, slag, hearth, finishing, blast, salt / roasting; suspension, dead, flash, sweet / roast. -acero asado; tostación; tostación en montón, final, escorificante, forzada; cocción, recocer, recocer al descubierto, al rojo, en caja cerrada; recocido blando, completo, en el vacío, gaseoso, isotérmico; acero asado, colado, fritado; cobre fritado, recocido; hierro colado. -wafer, grained metal, finegrained steel, coarse-grained steel. -galleta, galleta de metales, acero de grano grueso, de grano fino, correoso; cobre crudo, granulado, en cáscara; papilla; pan de oro, pan de plata, pan de licuación (cobre), plomo en panes.

Table 4. Objectual (Inanimate entities' features) pattern

In WINES ARE CLOTH, we find an interesting transposition of touch-related terms ("velvety", "silky") to wine flavour, equally present in both languages (4/4).

Worth highlighting are two different tendencies referring to metaphorical productivity in English and in Spanish. As regard farm machinery, the ratio English/Spanish terms is 6/2 in the metaphor An epicyclic gearing is a planetary gearing. Again, as in the previous section (organicist pattern), the number of metaphorical terms related to the field of mechanics is larger in English than in Spanish. A deeper study is needed to determine whether the productivity difference of metaphorical terms in these and other languages occurs in more cases of cognitive metaphors related to machinery and mechanics in general.

A different case is the metaphor METALS ARE FOOD. The productivity of Spanish terms is greater than in English in the three mappings found. In the case of the transposition of taste-related terms to describe metals' features, the ratio is 14/1. The term "ácido" has an equivalent "acid" in English; but "agrio", "dulce" and "semidulce" do not have a metaphorical term in English, but a specific technical one where the food metaphor is lost, i.e. "perished steel" ("acero agrio"), "soft steel" ("acero dulce"), "lowcarbon steel" ("acero semi-dulce"). The same happens with "wrought iron" ("hierro 
dulce") and "brittle iron" ("hierro agrio"). In the mapping "treating metals is cooking food', we found 12 metaphorical expressions containing the word "roast" in English, whereas in Spanish we found 22 compound terms containing the words "asado", "tostado", "cocido", "recocido", "fritado" and "colado". As we can see, only "roast" ("cocer") is shared in both languages. In the third mapping, 'Treated metals' appearance is food's appearance', the productivity is also in favour of Spanish terms, with 13 metaphorical terms against 4 in English. The terms "papilla" and "pan", and their compound forms are lost as metaphors in English.

Summarising the three metaphorical patterns (table 5) applied to the fields of earth sciences, agronomy and mechanical engineering, we can observe that the most productive pattern in number of terms is the humanizing metaphor, followed by the organicist and the objectual ones. Humanizing metaphors seem to be more complex than the organicist ones, including more mappings. The semantic distance from the human being to the universe, metals, minerals, rocks, rivers, water, wines and bees as the target domains is quite large; and, therefore, their degree of metaphoricity is very high (Cuadrado \& Durán, 2013a, p. 6).

Similarly, organicist metaphors seem to be more complex than the objectual ones, and comprise more mappings. Having the human or mammals' body features and patterns as the source domain, and rocks, mines, soils, plants, engines and machines as the target domain -all of a material nature except for plants that are living organisms-, the semantic distance between the body and inanimate matter is high. On the other hand, the objectual pattern mappings occur between similar level source and target domains in order to explain other natural objects, and wine and genes. Further studies are needed before we reach a more definite conclusion. But as far as we can see, the tendencies shown in the three analysed metaphorical patterns seem to confirm that the more anthropocentric the source domain is, the higher the metaphorical complexity and the degree of metaphoricity of the conceptual metaphors found in science and technology.

\begin{tabular}{|c|c|c|}
\hline $\begin{array}{l}\text { Metaphorical } \\
\text { patterns }\end{array}$ & Conceptual metaphors & Mappings \\
\hline \multirow[t]{4}{*}{ Humanizing } & -STARS AND PLANETS ARE PEOPLE & $\begin{array}{l}\text {-Groups of stars are families } \\
\text {-Star types are human traits }\end{array}$ \\
\hline & -STEEL IS A PERSON & $\begin{array}{l}\text {-Steel's life is human life } \\
\text {-Steel's features are human traits }\end{array}$ \\
\hline & $\begin{array}{l}\text {-ROCKS AND MINERALS ARE } \\
\text { HUMAN BEINGS }\end{array}$ & $\begin{array}{l}\text {-Rocks are human family members } \\
\text {-Rocks and minerals are social beings }\end{array}$ \\
\hline & -A RIVER IS A HUMAN BEING & $\begin{array}{l}\text {-A river's course is human life's cycle } \\
\text {-A river is a person }\end{array}$ \\
\hline
\end{tabular}




\begin{tabular}{|c|c|c|}
\hline & -WATER IS A HUMAN BEING & $\begin{array}{l}\text {-Water's life cycle is human life's cycle } \\
\text {-Water's features are human traits }\end{array}$ \\
\hline & -WineS ARE PEOPLE & $\begin{array}{l}\text {-Wine features are human character } \\
\text {-Wine's cycle is human life cycle }\end{array}$ \\
\hline & PLANTS ARE HUMAN BEINGS & $\begin{array}{l}\text {-Parts of a plant are parts of the body } \\
\text {-The plant circulatory system is the } \\
\text { body circulatory system } \\
\text {-Plant organization is human social } \\
\text { organization } \\
\text {-A plant's uncontrolled growth is an } \\
\text { attack }\end{array}$ \\
\hline & -BEES ARE HUMAN SOCIETY & \\
\hline Organicist & $\begin{array}{l}\text {-ROCK PROCESSES ARE } \\
\text { PLANT PROCESSES }\end{array}$ & \\
\hline & $\begin{array}{l}\text {-THE ENTRANCE INTO A PIT OR A } \\
\text { MINE IS THE HEAD }\end{array}$ & \\
\hline & -SOILS ARE LIVING ORGANISMS & \\
\hline & $\begin{array}{l}\text {-PLANT AND TREE activity CYCLE IS } \\
\text { A SLEEP-WAKE CYCLE }\end{array}$ & \\
\hline & -ENGINES ARE BODIES & $\begin{array}{l}\text {-The engine's carburettor is the } \\
\text { respiratory system. } \\
\text {-The engines' fuel conduction system } \\
\text { is the digestive system }\end{array}$ \\
\hline & -MACHINES ARE ANIMALS & $\begin{array}{l}\text {-Machine elements are parts of the } \\
\text { body } \\
\text {-Machines are animal species }\end{array}$ \\
\hline Objectual & $\begin{array}{l}\text {-ROCK FORMATIONS ARE } \\
\text { ARCHITECTURAL ELEMENTS }\end{array}$ & \\
\hline & $\begin{array}{l}\text {-GENES ARE CONTAINERS OF } \\
\text { INFORMATION }\end{array}$ & \\
\hline & -WINES ARE CLOTH & $\begin{array}{l}\text {-Transposition of touch-related terms } \\
\text { to taste }\end{array}$ \\
\hline & $\begin{array}{l}\text {-AN EPICYCLIC GEARING IS A } \\
\text { PLANETARY GEARING. }\end{array}$ & \\
\hline & -METALS ARE FOOD & $\begin{array}{l}\text {-Transposition of taste-related terms } \\
\text { to metal properties } \\
\text {-Treating metals is cooking food } \\
\text {-Treated metals' appearance is food's } \\
\text { appearance }\end{array}$ \\
\hline
\end{tabular}

Table 5. Summary of conceptual metaphors and metaphorical patterns studied 


\section{Conclusions}

The present analysis of metaphorical terms in three large specialised fields -earth sciences, agronomy and mechanical engineering- has supported the hypothesis that metaphor is central to scientific language and thought, not only on an exegetical or explanatory basis, but also on a constitutive basis. Although we had observed in the BDSTMM that a considerable number of terminological metaphors and metonymies had been found in isolation in scientific and technical literature, the paper highlights that the metaphorical expressions analysed are not always independent one from another; on the contrary, in many cases, their connected complex semantic networks constitute significant conceptual metaphors. Their rich powerful patterns unveil the mental mappings that support technical and scientific thought.

As in general language, in most of the cases of lexicalized metaphors, metaphorical mappings are still active and continue to generate new metaphors. The examples shown throughout the paper evidence the fact that a metaphor can be a very productive framing device in language because it provides support for human thought processes. So, when scientists try to express scientific findings (target domain), they call upon their previous knowledge not only from concrete domains but also from abstract representations (source domain) to provide a comprehensible structure to the former. That is, scientific concepts are often describable by mapping other concepts from total human experience, both of a common concrete nature (objects, human or animal body, etc), as well as from abstract experiences (character features, feelings, attitudes, etc.), and from human imagination.

From empirical data, we have shown that the metaphors found are all grounded in physical experience: in man's perception of himself as human, in the body functions, and in his perceptions of the material inanimate world around him, as it is evidenced in the nineteen conceptual metaphors discussed along the paper. A detailed analysis of the most productive conceptual metaphorical patterns -organicist, humanising, and objectual- within the areas of science and technology studied, verifies that the most prolific pattern is the humanizing one, the most anthropocentric, which has proven very rich in conceptual metaphors and different mappings. Moreover, humanizing metaphors are almost identical in English and Spanish, whereas the greatest differences in metaphorical terms are found within the objectual pattern.

Another significant finding is that similar conceptual metaphors are present in both languages, with interesting though not large differences in the number of lexical units linked to the conceptual metaphors. Thus, we may conclude that scientists' conceptual systems are either universal or highly widespread across languages and cultures. In this sense, the global scientific community shares similar conceptual metaphors to structure knowledge and to communicate scientific findings and their 
developments, though with different emphasis, at least according to the two languages and cultures analysed, English and Spanish.

Finally, the comparison of metaphor use in the languages studied has allowed us to pinpoint similarities and differences in English and Spanish, stressing the need for authorised translations, which are not always literal. The fact that most cognitive metaphors are active in both languages, with few lexical variations, opens the door to further research on the role of metaphor in constructing meaning within all branches of science and technology, and on its variations in different cultural contexts.

\section{About the authors}

Pilar Durán-Escribano (PhD) is an Associate Professor in the Department of Linguistics Applied to Science and Technology at Universidad Politécnica de Madrid (UPM). She has lectured and tutored English for Science and Technology and English for Academic Purposes to Mining Engineering and Geological Engineering students for over thirty years. Her research interests include the linguistic analysis and pedagogical applications of EST texts and academic genres, the application of the CEFRL directives (Council of Europe, 2001) to EAP teaching, and the study of metaphorical terms in geological and mining engineering. She has led and participated in several research projects, and published in top national and international journals.

Dr. Georgina Cuadrado-Esclapez is a lecturer of English for Academic and Professional Communication in the Department of Linguistics Applied to Science and Technology at Universidad Politécnica de Madrid. Her main research areas include semantics, didactics, cognitive linguistics and cognitive metaphor, particularly in science and technology. She has taken part in several research projects on Applied Linguistics and Cognitive Metaphor in specialized discourse and has participated in different international workshops and conferences. She has published in several national and international top journals (Annual Review of Cognitive Linguistics, IBÉRICA, RESLA, International Journal of English Linguistics, etc.).

\section{Acknowledgements}

The results of this paper were part of the research project: Bilingual Dictionary of Scientific and Technical Metaphors and Metonymies (cf. Bibliography), (2013-2015). Funded by Fundación Gómez Pardo (UPM) \& Colegio de Ingenieros de Minas de 
Madrid. Participants: G. Cuadrado (P.I.), Co-Investigators: I. Argüelles, P. Durán, MJ. Gómez, S. Molina, J. Pierce, M-M. Robisco, A. Roldán \& Paloma Úbeda.

\section{LFE Article history}

Paper received: dayth Month YEAR --- $15^{\text {th }}$ September 2016

Paper received in revised form and accepted for publication: $2^{\text {nd }}$ March 2017

\section{Bibliography}

Boyd, R. (1993). 'Metaphor and theory change: What is metaphor a metaphor for?' In A. Ortony (Ed.) Metaphor and Thought (pp. 481-532). Cambridge: Cambridge University Press.

Brown, T. (2008). Making Truth. Metaphor is Science. Illinois: University of Illinois Press.

Caballero, R. and Diaz-Vera, J. (2013). Sensuous Cognition. Explorations into Human Sentience, Imagination, (E)motion and Perception. Berlin \& New York: Mouton de Gruyter.

Ciapuscio, G. (2011). De metáforas durmientes, endurecidas y nómadas: un enfoque lingüístico de las metáforas en la comunicación de la ciencia. Arbor Ciencia, Pensamiento y Cultura, 187, 89-98.

Cuadrado Esclapez, G. (2010). Un sistema de engranajes es un sistema planetario: análisis de la metáfora cognitiva y los modelos mentales en la ingeniería. In T. Bungarten (Ed.), Akten des IX. Internationaler Kongress Der Europäischen Gesellschaft Für Fachsprachen (pp.1-9). Hamburg: Universität Hamburg.

Cuadrado, G. and Durán, P. (2013a). Proposal for a Semantic Hierarchy of Terminological Metaphors in Science and Technology. International Journal of English Linguistics, 3(4), 1-15.

Cuadrado, G. and Durán, P. (2013b). <<ROCKS ARE HUMAN BEINGS>>. Researching the humanizing metaphor in Earth Science Scientific Texts. Global Journal of Human Social Science, 13(7), 53-63.

Durán Escribano, P. and Argüelles Álvarez, I. (2016). Cross-Disciplinary Metaphorical Meaning Extension in the Creation of New Scientific Terms. In M.F. Litzler., J. García Laborda \& C. Tejedor Martínez (Eds.), Beyond the universe of Languages for Specific Purposes: the 21st century perspective (pp. 107-110). Alcalá de Henares: Publicaciones Universidad de Alcalá.

Evans, V. (2013). Metaphor, Lexical Concepts and Figurative Meaning Construction. Journal of Cognitive Semiotics, 1(2), 73-107

Fahnestock, J. (1999). Rhetorical Figures in Science. New York: Oxford University Press.

Fauconnier, G. (1997). Mappings in Thought and Language. Cambridge: 
Cambridge University Press.

Johnson, M. (1997). Embodied Meaning and Cognitive Science. In D. Levin (Ed.), Language beyond Postmodernism: Saying and Thinking in Gendlin Philosophy (pp. 148-175). Evanston, IL: Northwestern University Press.

Johnson-Sheehan, R. (1997). The Emergence of a Root Metaphor in Modern Physics: Max Planck's Quantum Metaphor. Technical Writing and Communication, 27(2), 177-190.

Kövecses, Z. (2010). Metaphor and Culture. Acta Universitatis Sapientiae Philologica, 2(2), 197220.

Lakoff, G. (1987). Women, Fire and Dangerous Things. What Categories Reveal about the Mind. Chicago: University of Chicago Press.

Lakoff, G. and Turner, M. (1989). More Than Cool Reason. Chicago: University of Chicago Press.

Lakoff, G. (1993). The Contemporary Theory of Metaphor. In A. Ortony (Ed.), Metaphor and Thought (pp. 202-251). Cambridge: Cambridge University Press.

Lakoff, G. and M. Johnson (1980). Metaphors We Live By. Chicago: The University of Chicago Press.

Lakoff, G. and Johnson, M. (1999). Philosophy in the Flesh. The Embodied Mind and its Challenge to Western Thought. New York: Basic Books.

Low, G. (1999). Validating metaphor research projects. In L. Cameron and G. Low (Eds.), Researching and Applying Metaphor (pp. 48-66). Cambridge: Cambridge University Press.

Musolff, A. (2009). "Progressive" evolution and "totipotent" stem cells: metaphors in British and German debates about the "life sciences". IBÉRICA, 17, 45-60.

Pragglejaz Group (2007). MIP: a method for identifying metaphorically used words in discourse. Metaphor and Symbol, 22, 1-39.

Robisco M M. (2011). Análisis Cognitivo de las preposiciones en torno al eje de verticalidad en el inglés para la aeronáutica. Madrid: Editorial Doppel.

Roldán-Riejos, A. and Molina Plaza, S. (2016). Home and Clothes: A Case of Prolific Metaphor Creation in Engineering (Spanish and English). SYNERGY, 12(1), 129-138.

Roldán-Riejos, A. and Úbeda Mansilla, P. (2013). Metaphor in the ESP engineering context. IBÉRICA, 25, 107-126.

Rosch, E. (1978). Principles of Categorization. In Rosch, E. \& Lloyd, B.B. (Eds.), Cognition and Categorization (pp. 27-48). Hillsdale, NJ: Lawrence Erlbaum Associates.

Salager-Meyer, F. (1990). Metaphors in medical English prose: A comparative study with French and Spanish. English for Specific Purposes, 9, 145-159.

Siqueira, M., Souto de Oliveira, A.F., Dienstbach Huber, D., Faé de Almeida, G. and Moreira Brangel, L. (2009). Metaphor identification in a terminological dictionary. IBÉRICA, 17, 157174. 
White, M. (2004). Turbulence and turmoil in the market or the language of a financial crisis. IBÉRICA, 7, 71-86.

\section{Dictionaries}

Allaby, M. (2003/2008). Oxford Dictionary of Geology and Earth Sciences. Oxford: Oxford University Press. Published online 2015.

Alonso Matilla, L. A. (2004/2009). Diccionario Oxford-Complutense de Ciencias de la Tierra, con Vocabulario traducido inglés/ español. Madrid: Editorial Complutense.

Atking, T. and Escudier, M. (2014). Oxford Dictionary of Mechanical Engineering. Oxford: Oxford University Press.

Beigbeder Atienza, F. (1988). Nuevo Diccionario Politécnico de las Lenguas Española e Inglesa. English / Spanish. New Polytechnic Dictionary of Spanish \& English Language. Spanish/English. Madrid: Diaz de Santos S.A.

Chhatwal, M. (1998/2004). Anmol's Dictionary of Geology. New Delhi: Anmol Publications,

Collins English Dictionary. <https://www.collinsdictionary.com/dictionary>

Cuadrado, G., Argüelles, I., Durán, P., Gómez, M-J, Molina, S., Pierce, J., Robisco, MM., Roldán, A. and Úbeda, P. (2016). Diccionario Científico-Técnico de Metáforas y Metonimias (EspañolInglés/Inglés-Español). Oxford: Routledge.

Howard, D. (2005). The Penguin Dictionary of Electronics. London: Penguin.

McGraw-Hill Education. (2000). The McGraw-Hill Dictionary of Scientific and Technical Terms (2000). New York: McGraw-Hill, 7th ed.

Oxford English Dictionary. <https://www.oxforddictionaries.com/english>

Park, C. and Allaby, M. (2007). Oxford Dictionary of Environment and Conservation. Oxford: Oxford University Press. Published online 2017.

Thrust, P. W. (Ed.) (1968/1990). Dictionary of Mining, Mineral, and related terms. Chicago: US Department of the Interior. 